Saudi Journal of Humanities and Social Sciences

Abbreviated Key Title: Saudi J Humanities Soc Sci

ISSN 2415-6256 (Print) | ISSN 2415-6248 (Online)

Scholars Middle East Publishers, Dubai, United Arab Emirates

Journal homepage: https://saudijournals.com

Original Research Article

\title{
Rural Low Income Reproductive Age Women's Health in Emohua Kingdom in Rivers State Nigeria and Growth in Agriculture
}

\author{
Maduawuchi Elem* \\ Sociology Department, Faculty of Social Sciences, Ignayius Ajuru University of Education Port Harcourt, Nigeria
}

DOI: $\underline{10.36348 / \mathrm{sjhss} .2021 . v 05 i 12.006}$

| Received: 29.11.2020 | Accepted: 14.12.2020 | Published: 30.12 .2020

*Corresponding author: Maduawuchi Elem

\section{Abstract}

The work is a quantitative research. It examines how health status of rural low income reproductive age women in Emohua Kingdom in Rivers State Nigeria can result to growth in agriculture of the people and Rivers State at large. The respondents are 60 rural reproductive age women who are farmers from the area. Similarly, related literature was reviewed. Thereafter, data were collected. The collected data were analyzed using simple percentage and Chi-square. At the end of the analysis, it was revealed that malaria, typhoid, diarrhea is among the common health challenges and that these negatively affect their agriculture production level. Based on this, the work recommends repositioning of Primary Health Care which should include free medical care for rural farmers, the establishment of health-agriculture policy that can stimulate both sectors simultaneously among others.

Keywords: Rural, Low income, Reproductive age women's health and Agriculture.

Copyright () 2021 The Author(s): This is an open-access article distributed under the terms of the Creative Commons Attribution 4.0 International License (CC BY-NC 4.0) which permits unrestricted use, distribution, and reproduction in any medium for non-commercial use provided the original author and source are credited.

\section{INTRODUCTION}

Globally, especially in Sub-Sahara Africa, rural population is peculiar. They are characteristically low income group who engage in primary production, mainly primary agriculture. In this, women of reproductive age equally stand out as the labor force. In Nigeria, this demographic characteristics and economic role of women generally is a permanent feature in all Nigeria population censuses. According to Ekong [1], there is a deficit of males between age 15-19 and 40-44 in rural areas. Similarly, Nigeria 2019 Projected Population reveal that reproductive age women constitute $49.32 \%$. Generally, reproductive age women whether in rural or urban areas constitute the labor force and they play very prominent role in procreation.

Of important here is that in developing economies this category of people serve as the main economic base in rural agriculture. They equally play service role to the urban area that depend on food produced by the rural area for their survival. Reproductive age women ability to perform these roles is dependent on their health status. This is because the synergy between health and economic activity is invaluable. It is only a healthy person that can be productive to sustain food security, even provide the needed labor supply for the manufacturing firms who depend on reproductive age women's children generally as their labor force.

\section{THE THESIS}

The relationship between state of health and productivity is obvious. Only healthy population can be productive. In health- wealth hypothesis, a positive correlation exist between health and wealth; healthier people work more and are physically and cognitively stronger and therefore more likely to be productive to earn higher income and can as a result accumulate more assets. This is akin to the saying that health is wealth and health is a valued possession. A healthy population is an engine house for economic growth (World Health Organization [2] Working Group Report 2002). In this respect, according to Josh [3], healthier people live longer and consequently have more opportunities to benefit economically from human capital investments.

Similarly early-life poor reproductive health, can, apart from lowering occupational status and earning of the person, can also led to theironparticipation in the labor force. Given this nexus between productivity and health status of labor force, weak reproductive labor force due to ill-health which takes the worker away from work, can result to lower occupational status, lower earnings. Going from this, the poor can die young and suffer from communicable 
diseases, malaria and perinatal conditions and nutritional deficiencies. In this regard, people of good health generally have better intellectual capacities, therefore can enhance enormous growth including agricultural growth. Deductively, good health is an asset for agricultural growth and development. So, the success of agricultural livelihoods of any given population depend largely on health status of its work force.

Incidentally, rural societies are not only poor but are populated by reproductive women who are farmers. Studies by Ogundipe, Ogunniyi, Olagunju and Asaleye [4] and Apata, Apata, Igbalayobi, Awoniyi [5] affirmed this. According to Ogundipe, Ogunniyi Olagunju and Asaleye [4] the prevalence of poverty is severe in rural area as about $80 \%$ of the population in the rural areas live below the poverty line with limited social and infrastructural services. Similarly, Apata, Apata, Igbalajobi and Awoniyi [5] in their study on the determinant of rural poverty in Nigeria, using small holder farmers in South Western Nigeria reveal that these group are not only disadvantaged, but are more vulnerable and majority of them are living in absolute poverty. In addition, majority of the population are undernourished. What this means is that high incidence of poverty and inequality is fundamentally inseparable evil or phenomenon in rural Nigeria.

As observed above, rural population is dominated by women. In this population, reproductive age women are phenomenal. Female share of agricultural labor (the primary occupation of the people) force is slightly less than half of the population. Rural agriculture is one of the highest employers of labor and a vital income generation sector. By this, food security and survival of the entire population rest on this age bracket in the rural area. As a neglected social group, all the indices of underdevelopment are visible. As a result of this, quality of life is low. For example, Elem [6] in a study of primary health care and maternal mortality in selected areas in Rivers State Nigeria, reveal that there is an existence of maternal mortality. And part of this problem is located in the prevalence of Traditional Birth Attendants, (TBA). The prevalence is made popular by cultural factors and absence of accessible public health care centres unlike the TBAs.

This finding has some relevance in the work of Omodu [7] who looked at alternative medicine practice in Rivers State. In this work, it was revealed that alternative medicine practice is patronized by low income people in the rural areas. The existence of this account for low health status of most people in the rural area. When these are contrast with the fact that Nigeria is currently the world headquarter of poverty, one will be able to appreciate the depth of the problem. It is on this basis that this work became imperative to examine the common health challenges among low income reproductive age women in Emohua and to identify the extent to which the so identified common health challenges affect growth in agriculture in Emohua.

\section{AREA OF THE STUDY}

Emohua kingdom is the headquarter of Emohua Local Government Area of Rivers State. The kingdom is made up of eight villages; namely Rumuche, Rumuohia, Rumuakunde, Mgbueto, Mgbuitawo, Isiodu, Elibrada and Oduoha. Political leadership of the kingdom rest on the paramount ruler, a reserve right for only true Mgboh sons, not for bastards. Geographically, Emohua is lies between longitude $44^{051}$ and $51^{051}$ north. It is bounded in the north by Odegwu, in the south by Degema and Asari-Toru LGA. In the west and east, the kingdom shares boundary with Isiokpo and Choba. Its land mass is estimated about $831 \mathrm{~km}^{2}$, approximately $321 \mathrm{sqm}$ and it has firm flat land, approximately $68 \mathrm{~km}$ away from the Atlantic ocean on the bonny. Given their firm table land, and some fresh and salt water environment, the primary economic activities is fishing and farming. Although other economic activities like craft work, hunting, business etc exist, but farming and fishing is the common economic activities.

As agrarian society, their agriculture is peasant type. As a result, they are peculiar in production of stable foods like the popular Ikwerre garri, vegetable and corn. Ikwerre garri and vegetable is the most priced stable food ingredients in Rivers State. It is considered the most nutritious of other stable foods from other ethnic groups in Nigeria. In Emohua kingdom, both Christian and traditional religion are practiced side by side, but Christian religion is the dominant one. The kingdom place much emphasis on male child as a result male leadership of the family is common. As peasant farmers with male dominance, women access to land is limited. In farming, widows and unmarried women suffer more because married women enjoy the privileges given to their husbands in access to land.

Like any other rural community in Nigeria, there is near absence of public facilities. In this respect, alternative medical practice is cherished. Just like any rural population in the third world, the population suffers from general health problem occasioned by poor nutrition. Besides, just like any other rural communities, there is obvious inequality in favor of men. This account for high incidence of poverty noticed in women.

\section{METHODOLOGY}

This study was carried out in Emohua Kingdom in Rivers State, Nigeria. Emohua is made up of eight (8) villages with Rumuche as the traditional headquarter and Mgboh family, the traditional custodian of the chieftaincy institution. The study is a survey research with the intent of establishing the type of health challenges rural low income women of reproductive age in Emohua suffer. Data were collected 
through primary and secondary sources. The questionnaire was revalidated by experts and were administered by two research assistants who is fully familiar with the terrain. The respondents were 60 rural low income farmers whose age falls from fifteen-fifty years. The respondents were purposively selected and the study took place from February 2020 to June 2020. The collected data were analyzed using simple percentage and chi-square statistical tools.

\section{DATA PRESENTATION}

Table-1.1: showing monthly income level of despondence

\begin{tabular}{|l|l|l|}
\hline Income & Frequency & Percentage \\
\hline $1,000-10,000$ & 30 & $50 \%$ \\
\hline $11,000-20,000$ & 18 & $30 \%$ \\
\hline $21,000-30,000$ & 8 & $13.3 \%$ \\
\hline $31,000-4,0000$ & 4 & $6.7 \%$ \\
\hline $41,000-$ above & Nil & Nil \\
\hline Total & 60 & 100 \\
\hline
\end{tabular}

Source: Fieldwork 2020

From the table, most of the respondents' income level per month is between $\$ 1,000-10,000$. This is followed by those whose income level is within $\$ 11000$ - \$20, 000. This income level is followed by those earning $\$ 21,000$ - $\$ 30,000$ which constitute
$13.3 \%$ and $\$ 31,000-\$ 40,000$ constituting of $6.7 \%$. None from the table earn N41, 000 and above. This means that majority of these $80 \%$ earn from $\$ 1$, 000$\$ 10,000$.

Table-1.2: Showing some of the health challenges these women suffer

\begin{tabular}{|l|l|l|l|l|l|l|l|}
\hline Item & SA & A & D & SD & - & SDV & Decision \\
\hline i) Cholera & $\mathrm{n}(\%) 15(25)$ & $\mathrm{n}(\%) 13(21.7)$ & $\mathrm{n}(\%) 18(30)$ & $\mathrm{n}(\%) 14(23.3)$ & $\begin{array}{l}- \\
x\end{array}$ & 1.01 & Agree \\
\hline ii) Typhoid & $17(28.3)$ & $14(23.3)$ & $19(31.7)$ & $10(16.7)$ & 28.3 & 1.00 & Agree \\
\hline $\begin{array}{l}\text { iii) Hepatitis } \\
\text { A \& B }\end{array}$ & $16(26.7)$ & $11(18.3)$ & $12(20)$ & $21(35)$ & 25.4 & 5.03 & Agree \\
\hline iv) Diarrhea & $27(45)$ & $6(10)$ & $22(36.7)$ & $5(8.3)$ & 3.15 & 1.77 & Agree \\
\hline v) Malaria & $9(15)$ & $23(38.3)$ & $24(40)$ & $4(6.67)$ & 0.25 & 05 & Agree \\
\hline
\end{tabular}

Source: Fieldwork 2020

From table 1.2 above, it is evidence that common health challenge respondents usual get is
Diarrhea $(55 \%)$. This is followed by malaria $(53.3 \%)$

Typhoid (51.6\%). The least is hepatitis (45\%).

Table-1.3: showing the extent to which these health challenges have affected agricultural productivity of respondents in Emohua Kingdom

\begin{tabular}{|l|l|l|l|l|l|l|l|}
\hline Item & SA & A & D & SP & - & SDV & Decision \\
\hline $\begin{array}{l}\text { i) Illness takes me away from } \\
\text { work. }\end{array}$ & $\mathrm{n}(\%) 29(48.3)$ & $\begin{array}{l}\mathrm{n}(\%) \quad 26 \\
(43.3)\end{array}$ & $\begin{array}{l}\mathrm{n}(\%) \\
3(5)\end{array}$ & $\mathrm{n}(\%) 2(3.3)$ & - & $x$ & Agree \\
\hline $\begin{array}{l}\text { ii) It causes low productivity } \\
\text { and food scarcity. }\end{array}$ & $32(53.3)$ & $20(33.3)$ & $1(1.67)$ & $7(11.7)$ & 0.24 & 0.48 & Agree \\
\hline $\begin{array}{l}\text { iii) It brings about } \\
\text { backwardness in } \\
\text { development. }\end{array}$ & $25(41.7)$ & $14(23.3)$ & $8(13.3)$ & $15(21.7)$ & 2.33 & 1.53 & Agree \\
\hline
\end{tabular}

Source: Fieldwork 2020

From the table it is clear that the prevailing health conditions affect these women's agricultural activities as over $80 \%$ of them agree that sickness takes them away from their farm work while over $80 \%$ is of the opinion that their absence from work do cause low productivity and food scarcity. This is against the background of those that claim that it negatively affecting their development. 
Table-1.4: Showing the ways to reduce the impact of these health challenges to bring about improvement in agricultural productivity of rural low income women in Emohua.

\begin{tabular}{|l|l|l|l|l|l|l|l|}
\hline Item & SA & A & D & SD & - & SDV & Decision \\
\hline $\begin{array}{l}\text { i) Provision of functional health } \\
\text { centres. }\end{array}$ & $\mathrm{n}(\%) 5(25)$ & $\mathrm{n}(\%) 8(40)$ & $\mathrm{n}(\%) 3(15)$ & $\begin{array}{l}\mathrm{n}(\%) 4 \\
(20)\end{array}$ & $\begin{array}{l}- \\
x\end{array}$ & & Agree \\
\hline $\begin{array}{l}\text { ii) Introduction of free medical } \\
\text { programme for rural women. }\end{array}$ & $11((55)$ & $6(30)$ & $2(10)$ & $1(5)$ & 0.01 & 0.10 & Agree \\
\hline $\begin{array}{l}\text { iii) Mass literacy programme } \\
\text { and enlightenment companions. }\end{array}$ & $7(35)$ & $9(45)$ & $3(15)$ & $1(5)$ & 2.45 & 1.57 & Agree \\
\hline
\end{tabular}

Source: Fieldwork 2020

From the table the provision of free medical has over $80 \%$ acceptances as the prime therapy to reduce ill-health that negatively impact on their agricultural productivity. This is followed by mass literacy programme and enlightenment campaign. The least is provision of provision of functional primary health care which has $65 \%$ for agree and strongly agreed.

\section{IMPERICAL LITERATURE}

There are abundant empirical literature in line with this work. Ajani and Ugwu [8] worked on the impact of adverse health on agricultural productivity of farmers in Kainji Basin in north-central Nigeria. In this work, the scholars used stochastic production frontier approach and it was revealed that the ill-health of farmers in Kainji Basin has greater share in the inefficiency of the farmers. By this, the work further conclude that farmer's ill-health results to decline in household income, food security in the area and severe deteriorating household livelihood. Similarly, the finding of this work is equally relevant in Aminu, Idris and Ambali [7] work on the effect of ill-health on technical efficiency of dry season vegetable farmers in Ojo Local Government Area of Lagos State Nigeria. These scholars used eighty (80) farmers and discovered that the health of these farmers effect the technical efficiency of the dry season vegetable farmers. As a result of this, these farmers productivity level was negatively affected.

In a related work on the impact of health services on agricultural labor productivity by Combary [9] reveal similar result. Infact, it was discovered that households that use the services of HSPC to treat their sick members during farming activities significantly improved their farming production. In the same vein Loureir [10] in a study titled "farmers' health and agricultural productivity in Norway" using stochastic frontier regression techniqueconclude that differences in farmers' health level defined their productivity level.

Apart from these scholars, International Assessment of Agriculture Science Organization and Development [11] in their executive summary on their work titled "Agriculture: How is food production affecting health?" conclude among other things that illhealth in farming community can reduce agricultural productivity and that malaria is a major cause of agriculture occupational death which yearly estimate is at 170,000. This finding finds relevance in International Food Policy Research Institute [12]. In this work, it was observed that both ill-health and agriculture is essential ingredient in the fight against poverty. Secondly, that malaria, diarrhea, respiratory infection, malnutrition are among the sickness modern farmers face.

Emphasizing this link, the report asserts that malnutrition and poor health are prevalence among agricultural producers and that agriculture productivity is negative as a result. In this report, the effect of illhealth is significantly observed in high health cost, leading to absenteeism from farm work, reduced farmers ability to generate income, thereby resulting to income losses in the local and national economy. Going further, the study using HIV/AIDS to illustrate this affinity between health and agricultural productivity, this work revealed that studies shows that countries with HIV/AIDS do experience cash and labor shortages and tend to switch crop types, reduce crop area and livestock use. These ultimately reduce productivity, loss of farm specific knowledge and reduce institutional capacity in the agricultural sector.

Finally this work corroborates the revelation of Steven and Marc [13, 14] in their study titled human health effects of agriculture and illnesses. According to these scholars, respiratory diseases are common among agriculture farmers and it is due to their exposure to dusts. The relevance of this in the present study is huge as farming is done in dry season. Accumulative effect of this is seen in malaria and respiratory disease like pneumonia.

\section{CONCLUSION AND RECOMMENDATIONS}

Drawing from the findings above, it is evidence that there is a strong relationship between the health of rural women of reproductive age who are in agriculture and the growth in agriculture. This nexus between health and work is such that health status determines the level of productivity of any worker. It is based on this that the peoples' income level is low since health problem takes them away from work.

\section{RECOMMENDATION}

Based on these findings, the following recommendations are offered. Firstly, there should be a repositioning of Primary Health Care (PHC). 
Repositioning strategy is invaluable given PHC place in addressing rural health challenges. In this regard, PHC should provide free medical care for common rural health problems like malaria, typhoid and diarrhea especially to rural women farmers of reproductive age. In this repositioning process, PHC staff posting should note the staff understanding of the community culture especially their language. This is imperative because the ability to understand the language of the people creates confidence on the rural people to patronize the available PHC facility. In addition, it will reduce communication problem between the staff and the rural people since cultural factors drive the interactions in the community.

Again, government should provide accommodation for staff of PHC in the same premises as this will make their services readily available irrespective of the time health challenge arises. In a similar vein, a standby two and functional ambulance cars with at least, two drivers should be provided. The drivers of this ambulance must benefit from PHC accommodation and must be indigenes of the place that is familiar with community terrain. Finally, in this repositioning exercise, government should develop health-agriculture policy that can stimulate both sectors simultaneously. In this respect, health insurance scheme for rural farmers should a major component of such National health insurance scheme since it addresses Out-Of-Pocket (OOP) problem in health.

Secondly, there should be empowerment programme for these women especially educational empowerment. When this is done, it will enable them among other things note common signs of ill-health before it weigh them down. Through this empowerment programmme, they can diversify their resource base. This way, they will be able to apply modern farming technique as against their use of crude farming method which will yield more growth than their current method.

\section{REFERENCE}

1. Ekong, E.E. (2003). An Introduction to rural sociology. Dove Publishers, Uyo, Nigeria.

2. World Health Organization. (2002). Working group report on health, economic growth and poverty reduction. Geneva world Health Organization.
3. Josh, G. (2018). Health and human capital. https://gps.ucsd.edu/news-events /news/healthand-human- capital.html accessed 04/7/2020.

4. Ogundipe, A. Ogunniyi, A., Olagunju, K; Asalaye, A.J. (2019). Poverty and income inequality in rural agrarian households of Southern Nigeria: The gender perspective. The open agriculture Journal 13.

5. Apata, T.G, Apata, O.M., Igbalajobi, O.A., \& Awoniyi, A. (2010). Determinants of rural poverty in Nigeria. Evidence from small holder farmers in south-western Nigeria. International Journal of Science and Technology Education Research 1(4) 85-91.

6. Elem, M. (2015). Primary healthcare and maternal mortality in selected areas of Rivers State, Nigeria. A Ph. D paper represented to University of Port Harcourt Graduate School.

7. Aminu, F, Idris, A., \& Ambali, O. (2013). The effect of ill-health on technical efficiency of dry season vegetable farmers in Ojo Local Government Area of Lagos State, Nigeria. Journal of Agriculture research, 1(8) 108-113.

8. Ajani, O.I.Y., \& Ugwu, P.C. (2008). Impact of adverse health in Kainji Basin North-Central Nigeria using a stochastic production frontier approach. Trends in agriculture 1(1) 1-7.

9. Combary, O.S. (2016). Impact of health services on agricultural labor productivity of rural households in Burkina Faso. African Growth and Development Policy Working paper.

10. Loureir, M.L. (2009). Farmers' health and agricultural productivity. Journal of agricultural economics, 40(4).

11. International Assessment of Agriculture Science Organization Technology for Development executive summary of Synthesis Report (April 2008).

12. International Food Policy Research Institute. (2006). A 2020 vision for food, Agriculture and the environment report.

13. Steven, K., \& Marc, S.C. (2001). Human health effects of agriculture: Physical diseases and illness. National agricultural safety data base.

14. Nigeria. (2019). Projected population. https://www.worldomieter.infer.ng. 